\title{
The Applied Sociology of Tourism. The Up Skills of the Facilitator in the Italian Hospitality Industry
}

\author{
Nicolò Costa \\ Sociology of Tourism and Local Development State, University of Rome Tor Vergata, Rome, Italy \\ Email: nicocosta@tiscali.it
}

Received May 30 $0^{\text {th }}$, 2012; revised June 30 $0^{\text {th }}$, 2012; accepted July 20 $0^{\text {th }}$, 2012

\begin{abstract}
The sociology of tourism can be considered applied sociology. Therefore, it is necessary to ascertain the up skills of the sociologist in the process of tourism planning. The present paper refers to the idea of philosophic practitioner as a theoretical model and considers the sociologist as a facilitator of local tourism development. To this purpose, I discuss some topics and working tools that can be used when the sociologist is asked to help local stakeholders create significant involvement of the local community. In particular, I propose some self-assessment tools to be included in a tourism process centred on local participation. The paper focuses on fundamental questions concerning the techniques of bottom up regulation and the techniques to facilitate the passage from individualism to collaborative marketing in order to attract visitors suitable to the destination. The discussions are based inductively on tourism economic policies initiated in Italy to create collaboration between local institutions and enterprises aimed at integrating local resources (accommodation structures, transport, gastronomy, art and archaeology, etc.) and creating districts or systems of Made in Italy hospitality. The results indicate the sociologist of tourism as a facilitator of the collaborative partnership in support of the destination management. Many difficulties in creating tourism districts or systems are due to the absence of this type of professional figure.
\end{abstract}

Keywords: Community; Local; Facilitator; Self-Assessment Tools; Local Tourism Development; Participatory Planning; Made in Italy Hospitality Industry

\begin{abstract}
Aim and Method
The aim of this study is to define the most effective and efficient socio-organizational procedures in the realization and management of local tourism development based on collaborative marketing (Aas, Ladkin, \& Fletcher, 2005; Fyall \& Garrod, 2005; Branwell \& Lane, 2000; Dredge, 2006a; Naipaul, Wang e Okumus, 2009) between public projects and private initiatives, but also between territorial public institutions and between companies (belonging to the same or different sectors) operating in Italian tourist incoming. It is argued that the "collaborative communities" provide a useful lens for understanding the tourism planning between government, tourism producers and civil society and, as such, have the potential to inform a participative destination management policy and practice.

The guidelines or planning procedures are based on the following presupposition: social exchange, composed by trust and reputation (not very present in hospitality), precedes and facilitates the economic exchange among the locals; this allows the development or territorial marketing plans to be the substance of the tourism system or district because it is managed by players who generate and receive trust and reputation.

The development plan, technically well written and a shared effort, should make use of continuous guidance by the applied sociologist, an expert in economic and geographical analyses of destinations. The sociologist works within models of consensual town planning, including Strategic Plans. He is charged by a Promotion and Management Committee with the task of putting into practice the few or many local skills and energies so that they can generate creative groups aimed at defining collec-
\end{abstract}

tive businesses destined to endure in time and at delineating good practices of a hospitable city with the residents and visitors (Costa, 2008). The applied sociologist as facilitator is a mediator (a true go-between) between knowledge of the tourism market and innovative activities of the companies that develop collective businesses with local bodies, thus acting as a meta-manager of development (on the role of mediators of knowledge in general, cf. Lopez-Cabrales, Perez-Luno, \& Valle Cabrera, 2009; Cooper, 2006). The mediation gives positive results in terms of facilitation of aggregative processes, of empowerment of the human resources present in hospitality, of guidance of the local players toward the realization of a precise Network Project (Dredge, 2006a; Dredge, 2006b).

The present study is a methodological contribution aimed at defining the guidelines of territorial planning centred on the involvement of the stakeholders in planning and managing network products. These network products are engineered around natural and cultural primary resources, which by themselves prompt a trip, or around secondary/support resources, interconnected and improved to form a unique and appealing attraction (Godfrey \& Clarke, 2002; Ritchie \& Crouch, 2005), reconciling promotion and marketing of the supply (Ejarque, 2009). This paper does not teach how to write the Local Tourism Development Plan but how to have the Plan written (learn to learn) by the local players by sharing knowledge that is implicit or internal to the single organization and explicit or formal knowledge codified in documents and projects.

It demonstrates that the sociologist of local development is able to increase profits for those who have something to exchange so as to merit receiving something in exchange (linked 
business). Therefore, the research is professionalizing and seeks to demonstrate how a local development sociologist can play the role of facilitator/empowerer/guide of aggregative processes (public and private decision-makers) for the planning and management of a hospitality network for development regulated via bottom-up consensus. It contributes to the debate on the skilled worker (Ebit, 2008) and on the competencies of local tourism development professionals (Costa, 2005; Biork \& Virtanen, 2005).

The study method consists in consultation of the Italian socio-economic and territorial literature on tourism and local development. The basic theory is that of social exchange as a presupposition favourable to economic exchange and to the practical realization of territorial planning projects to integrate local resources. To this end, the perception of the local players, consisting of the assessment of costs and benefits and of a more general satisfaction with the experience induced by tourism development, can be measured to establish the attitude toward one or more specific hospitality projects (Mason \& Cheyne, 2000; Jones, Jurowski, \& Uysal, 2000; Tosun, 2002; Nunkoo \& Ramkissoon, 2007; Tovar \& Lockwood, 2008, for the theory and the research method).

The international literature is hybridized with the professional experience of a sociologist-facilitator acquired during the start-up of Local Tourism Systems (e.g. La Spezia), the integration of cultural events and territorial marketing (e.g. Festival of Literature in Mantua, Festival of Ravello with the local tourist consortium and the Foundation of the Festival), Strategic Plans (e.g. that of Vasto San Salvo in Abruzzo) or Structural Plans (e.g. at Cetraro in Calabria or Fiano Romano, a town near Rome, or in the district of Acilia in the Municipality of Rome). In each of these cases, the participatory planning was guided by an urban planner, a graduate in architecture (sometimes an archistar like Vittorio Gregotti in the case of Acilia). The sociologist-facilitator (the author of the present article) used the self-assessment instruments described in this paper, included in the Italian debate on Made in Italy tourism districts or systems.

\section{The New Professional Framework: The Applied Sociologist of Tourism as Philosophic Practitioner}

The sociology of tourism as applied sociology (Dasgupta \& Driskell, 2007; Steele \& Price, 2008) faces a serious limitation: in Italy, but probably in many developed countries, there are no university courses with curricula expressly designed to train the sociologist of tourism and local development by combining education and practical training. The history of sociology of tourism in the USA and other English language countries (Nash, 2007; Apostolopoulos, Leivadi, \& Yannakis, 1996) and in France, Germany, Spain, Poland and Italy (Dann \& Liebman Parrinello, 2009) highlights the predominance of macro-theory over practical methods that could make the sociologist of tourism a professional who could influence the policies of local institutions and enterprises. Even when the sociologist uses the case-study method or participatory observation or comparative or quantitative methods, the empirical analysis leads to theoretical results that are little used (or not used at all) by the tourism players. Indeed, in the second chapter of Holden (2005), dedicated to the sociology of tourism, there is a clear concep- tual break between the first part presenting some macro-theories (structuralism, functionalism, conflict theory, phenomenology) and the second part describing empirical studies on tourist behaviour (starting with the socio-cultural impacts of tourism and the local community): in other words, the empirical studies are not guided by the theories. In reality, "great narrations" and "great theories" belong to the modernity of the $19^{\text {th }}$ and $20^{\text {th }}$ centuries. Today the sociologist is an "interpreter of culture"; having abandoned the conviction of controlling the social totality, he becomes a consultant who conducts research to serve civil society and political society with multiple and variable points of view, applying to his activity the post-modern paradigm of inter-disciplinarity and the paradigm of pragmatism aimed at solving problems in what seems the best way at the time. There is no profound truth and no prophecy about the future.

In Great Britain, John Tribe (2002, 2009) has delineated the figure of philosophic practitioner as a theoretical model of the new tourism player, trained with a mix of professional competencies and liberal knowledge. This approach is a point of reference for the present study, even though Tribe includes sociology among the liberal and reflective sciences and not among those that provide professional and reflective competencies (e.g. law, economics, marketing). Tribe's model has sparked a discussion on interdisciplinary competencies and, above all, on the hybridization of knowing with know-how, of knowledge with competencies, in terms of training programs in tourism and hospitality. The question about the sense of truth, beauty and virtue in tourism practices is acceptable if one then provides advice on how to improve erroneous practices, to eliminate ugliness or to indicate procedures for a possible good life. If the discussion is closed within the world of theorists (academics), the risk (especially for the sociologist) is to lose contact with the social reality and to raise questions exclusively within the community of experts, far from the changes occurring outside of it.

The perspective of the philosophic practitioner, who combines liberal-reflective and vocational-professional knowledge, is convincing: it can make up for the discrepancy between theory and practice. Therefore, the sociologist of tourism must also open up to the managerial implications of theories and help solve practical problems posed by the political and economic players operating in tourism and hospitality. And this must be accomplished by working with them and not "above" them seated on a pile of books scrutinizing tourism events in order to criticize them (for the limits of critical sociology applied to tourism, Costa \& Martinotti, 2003). If the sociologist of tourism is a philosophic practitioner, i.e. applies himself to the solution of problems, he can then teach others "how to" become a philosophic practitioner who works in public institutions or in tourism companies.

Hence, the present paper is a contribution to the training of the sociologist as philosophic practitioner who works in close connection with local development planners and contributes with up skills to urban, rural and environmental regeneration. Above all, he is recognized for his abilities as a socio-economic analyst of resources to be improved and of the impacts of tourism on the local community, and thus as a facilitator of good practices that generate collaborative partnerships to attract visitors and make them spend their money at the destination (Costa, 2005, 2008; Costa \& Testa, 2012; Biork \& Virtanen, 2005). For this reason, it is appropriate to describe the up skills of the ana- 
lyst-facilitator of local tourism development or of the post-Ford hospitality industry, as a specific professional figure of philosophic practitioner.

\section{LTS, CD, TD: Toward an Industry of "Made in Italy" Hospitality?}

The tourism development model was established by Italian legislation as a Local Tourism System or LTS (art. 5 Law 135/ 2001). However, the basic ideas were the same as the one drawn up by the Tourism District established by the Region of Sicily based on art. 7 of L. 15 September n. 10 and the Disciplinary Regulation (D.A. n. 4 of 16.02.2010) which literally reproduced its mandate and guiding idea, namely to facilitate the effectiveness of the economic players at the level of the supply chain in order to promote and market innovative products (Della Corte, 2009; Sciarelli, 2007; Dall'Ara \& Morandi, 2006; Lazzaretti \& Petrillo, 2006).

With the promotion of inter-organizational models, the legislation sought to initiate a process in which competition and cooperation between public institutions and private companies, alone or in partnership, could alternate so as to move ahead with product innovations and to attract tourist flows and expenditures to the destination, generating new jobs and growth of the gross domestic product (for LTS, cf. Dall’Ara \& Morandi, 2004; Lazzaretti \& Petrillo, 2006; Sciarelli, 2007).

This approach was borrowed from the Made in Italy "Industrial districts", which were also established by Italian legislation (law no. 371 of 1991) and subjected to attempts at protection in terms of certification of the final product and of the Italian concept of enterprise, with specific values that characterize the Italian mode of economic development. In fact, the Made in Italy of industrial districts was publicly praised by President Clinton during the G7 meeting in 1994.

There is a thread linking the sectorial interdependences of tourism with the image of Italy in the world. The excellence in archaeology, art, food and beverages, fashion, interior design, industrial design, cinema and sport has something in common with the touristic trip: the productive use of visual culture. The culture of images and the economy have long been linked; they are doctrines that are hybridized to generate an added value in aesthetical terms, a policy and a poetry of taste applied to goods (Costa, 2009). Why not reproduce their good practices in tourism? There is a current broad political debate on Made in Italy and the difficulties in protecting it from the unfair competition of counterfeiters. This internationally successful model should be defended and strengthened in the era of globalization, extending its factors of success to other sectors such as tourism but also to "cultural districts" or CD, which are also planned at the regional level but with little success (as supported by Sacco \& Tavani Blessi, 2005). In reality, these attempts always make reference, directly or indirectly, to the input-output of independent financing, which guarantees the persistence in time of the experiential tourism economy and of mobilities (cf. Ciapetti, 2010). Therefore, the CD should be considered sub-types of tourism districts or TD, and the great contributions of researchers to CD should be reproposed as tourism-culture districts within the renewed LTS or the Sicilian TD, without useless overlaps and "competing arguments". Hence, the CD should be included in a broader territorial marketing program centred on the knowledge and satisfaction of customers subdivided by trip variables (residents, day-trippers, tourists, business persons) or by socio-demographic lifestyles and spending capabilities (youths on school trips, elderly people with a lot of free time, traditional middle-class families). The improvement of resources with personalized services based on the target is the approach that also involves $\mathrm{CD}$, which work if the demands of cultural tourists are satisfied.

However, there is a formal public awareness that Italian economic development, freed from top-down directives and orders but supported by targeted provisions, is based on competition for the improvement of performances already present in the minds of the local operators. There are vital energies available locally for self-coordination within territorial and cognitive infrastructures guided by national policy, an effective economic policy of Made in Italy hospitality that replicates the successes of the industrial districts, now considered a tradition of the Italian path to modernization within the international division of labour.

In short, LTS, TD and, I would add, CD are variants of a hospitality industry - all to be planned and managed-which plays an active role in attracting the "gaze" (Urry, 1990) of customers by combining the creativeness of operators in sectorial interdependences among culture, economy, society, territory, environment, cultural resources, transportation and tourism. The organizational receptacle- be it LTS or DT - is defined by the actions agreed upon among the players involved in the bottom-up development. In fact, tourism districts, theoretically continuous with Made in Italy industrial districts (Costa, 2009), are characteristic because the collective actions, generated by territorial proximity, maximize the genius loci and local traditions and sell products effectively sought and chosen by the segments of tourist demand, increasing their sales (measured by cash flows). LTS, TD and CD can be understood as contributions or experiments that converge toward a Made in Italy hospitality industry, given certain conditions and procedures of integration of resources and players. Therefore, if Made in Italy enterprises play an important operational role (from design of the hotels to organization of events to prolong the tourism season), then we can hypothesize a Made in Italy hospitality district, defined by local specificities. Yet, this has not occurred thus far and is merely a research and planning hypothesis. There are no good practices to be studied with benchmarking.

The principal differences between industrial districts and tourism districts are that the hospitality players sell experiences and relationships (people move, not goods), that the place of production (goods and services of incoming) and the place of consumption coincide, and that the industrial district arises from the autonomy of civil society while the TD must have public leadership because many environmental and cultural resources are assets of administrations and must remain so (Costa, 2009). While a clothing company can stock its goods and have sales, a hotel manager seeks to sell accommodation. If unsold, it cannot be stocked because he produces and markets services related to the time spent, to the immateriality expressed by a room or a meal. In this context, the collective logics of tourism operators require territorial and experiential marketing different from industrial marketing aimed at selling the greatest quantity of goods in a market assumed to be in continuous growth. In tourism, relationships are marketed because the tourist, satisfied with the service, can increase the reputation of the structure and the number of its customers by means of advice to relatives and friends, positively influencing their decision-making processes (word-of-mouth marketing). Manufacturing sells goods, tour- 
ism sells relationships centred on the planned and perceived quality of services.

The mix of public and private services characterizes the marketing management of the tourism destination. Collaborative partnerships arise from effective exchanges among local talents (Fyall \& Garrod, 2005, Watkins \& Bell, 2003). These connective intelligences of the network (Dredge, 2006a), although belonging to different sectors (from agriculture to culture, from transport to hospitality, from food and beverages to events), converge toward a hospitality model that renders unique and high-quality the experiential products, which can be acquired only in the tourism district. If this convergence on the improvement of services and the shared realization of network products due to both geographical proximity and collaborative desires is realized, we can speak of "Made in Syracuse" or "Made in Assisi" TD because the local scale reinforces the national image, understood as a melting pot of diversity.

Understanding "how to do" bottom-up collaboration to generate successful innovations means initiating the first phase, namely the Promotion and Management Committee of a Network Project, whatever might be its denomination. This step forward is carried out in the (ideal and regulatory) perspective of the hospitality industry, in the inclusion of talents belonging to a broader local economy than the "restricted" tourism industry.

Several phases are proposed so that the Made in Italy hospitality network can be initiated following an appropriate methodology. Indeed, as an old proverb states, "well begun is half done”. In the more formal language of territorial planning, it can be said that we can interpret the fate of the process of product integration and bottom-up participation from the DNA of the Promotion Committee of a strategic or structural plan of the hospitable city, of a network of restaurants and typical agricultural products, of a tourism-culture district or of a local tourism system. The modalities by which the Promotion Committee involves the players to "put them to work", together with the reputation of and trust in the local talents asked to exchange information and services, contribute to the collective ability to generate pro-tourism social and intellectual capital, with a focus on the satisfaction of the resident population, the satisfaction of the local hospitality and transport entrepreneurs and workers, but especially the satisfaction of the types of tourists to be attracted and entertained by improvement and diversification of the local offer.

\section{Neo-Community and Cosmopolitan Self-Assessment of the Destination}

\section{Communicative Rationality, General Strategy and Strategic Projects}

In the diagnosis of the destination, the Promotion Committee, helped by a facilitator, initiates thinking on guidelines or points of no return during introductory forums. The concepts of strategy, collaborative marketing, network and system, glocalism are defined because the local élite, which started the process, believes in communicative rationality: access to information develops competencies and reduces asymmetries among those who wish to exchange learning to initiate profitable business relationships (the most horizontal ones possible) (Dredge, 2006a; Dredge, 2006b). Different people interpret networks differently and their flexibility should be viewed as an advantage in "fa- ciliating” understanding of the political complexities of collaborative planning (Dredge, 2006a: p. 579).

The local élite is part of the initiation of the hospitality industry network but knows that the final choices also involve the exclusion of those who do not change with change, who do not have specific skills or services to be improved, because not everybody can exchange with everybody but many with many (many-to-many relationship) in defining the strategic or structural or territorial marketing plan. The presentation of these strategic ideas begins to delineate a strategic vision, induced by the local élite.

The sociologist/facilitator poses the problem of eliciting the management knowledge of the locals: he knows the methods by which to transmit the knowledge accumulated from education or experience at the moment it is actually used in the hospitality industry (Turkson \& Riley, 2008). He knows how to define the importance of the process of self-assessment of the strategic plan so that when he first introduces the public forum with a talk the local élite immediately understands that the applied knowledge of the facilitator comes from experience, from his direct commitment in the Made in Italy hospitality industry. The sociologist/facilitator contemporaneously appears as an academic with formal knowledge encoded in books and articles he has written on local tourist development and as a partner who knows the real problems of the entrepreneurs, the workers and the public administrators. He wants to help them in a friendly way to bring out their hidden knowledge, the knowledge learned with experience and made available in the public forum. The forum is a working group in which the situation is not that of someone who teaches and others who are taught; all the stakeholders participate in a learning community that will develop self-assessment instruments to program the tourism from the point of view of the local community (Reid, Mair, \& George, 2004).

Clarifying certain guiding ideas at the beginning of the process is useful so as not to find them unresolved when the process is well on its way to a necessarily defective operation, with consequent costs (vetoes, disagreements, withdrawals, etc.) to repair the breakdowns of the system or network or district during the course of the work. Nevertheless, the proposed strategy sensitizes but does not convince, does not guarantee that people, even if convinced, will begin to work in a group and will automatically generate combined actions. Therefore, in addition to the "exposition" of ideas, it initiates a change of perspective. People listen but do not change their behaviour because of that; communicative rationality generally orientates people but does not per se prompt them to act and to change their behaviour.

In the introductory forum, the Promotion Committee, via the self-assessment, encourages the locals to look with an "outsider's" eyes at the local resources and eventual projects for enhancement of the immaterial and material patrimony. In this way, it simply seeks to know the pre-conditions and socioterritorial motivations to which is added inter-organizational innovation aimed at guiding local tourist development. It verifies the departure level following the introduction of the new guiding ideas. This and nothing more. And it often receives confirmation of the "limits" to participation more than positive surprises about the departure levels.

In reality, during the initial public forums and in the topical focus groups, the locals are not able to assess a strategy, consisting of so many numbers and so many ideas: the people often have cultural "limits" or little experience in discussions of pro- 
activity and of a general vision based on the evaluation of impacts at the level of sectorial inter-dependences, external diseconomies and long time periods (Tosun, 2002). Instead, they are able to think about precise initiatives; they activate their inductive thinking and then, guided by the facilitator, develop proactivity and vision. Therefore, the initial phase mainly involves the assessment of hypotheses of strategic projects in order to establish whether to create a territorial network or not, based on the costs and benefits but certainly also on more general values like the collective well-being and the sustainability of the projects. Hence, it is more effective to present strategic projects rather than to merely play the top-down educational role in explaining what is a territorial strategic plan or a territorial tourism marketing strategy. We are dealing with understanding how to encourage, initiate and manage the self-thinking ability of the residents concerning the advantages of collaboration. We are dealing with modelling the community's support of a project, included in a very loose strategic vision which combines the local resources to increase the attraction of the interconnected places, balancing the satisfaction of the residents, the workers and the tourists (Nunkoo \& Ramkissoon, 2010).

The very fact that the strategic project involves people who did not know each other prior to the public forum (e.g. the owners of second and third houses who live in the place parttime, along with incoming tour operators or the creative directors of the local museums or the local environmental associations) is a good beginning to recognize a limit to participation: the physical co-presence and the dialogue between bearers of different visions and interests is already an improvement in interpersonal relationships. This creates a social capital favourable to the hospitable city (Costa, 2008); at the very least, it encourages involvement in the neo-community formed by locals and open to the current visitors and it generates dialogue (Reid, Mair, \& George, 2004).

\section{Strategic Projects on Information Flows and Spatial Mobilities}

Since local communities are not very aware of the new society of information flows and new spatial mobilities (Adey, 2010; Urry, 2007; Sheller \& Urry, 2004), there is the matter of empowering the locals so that they perceive the benefits and costs of projects of realignment to the new experiential economy, to the post-modern hospitality industry. Therefore, it is necessary to convince them of the advantages of the change of cognitive paradigm and strategic perspectives by means of one or more general projects centred on information flows and spatial mobilities in order to remove any resistance to opening up to the communicational and interpersonal interconnections with outsiders put in motion by contemporary society.

A first guiding idea is the following: argue convincingly that there is a positive correlation between the satisfaction of residents with the services currently used and the acceptance of services used by “outsiders". This guiding idea can be used to generate the conviction that planning centred on the visitors can produce benefits for the residents. This implies a change of perspective in urban and territorial planning, passing from immobility to mobility. Passing from the image of the immobile society to the local society as a node of a dynamic network, a local society that can be regenerated merely by mobilities, is a different way in which administrators and many residents begin to see themselves, starting with the personal story of whomever has been rooted in the territory for a long time. And this is problematic. The shift of focus is already a problem for whomever is dissatisfied with his residential life and looks askance at the idea that the administrators should think about the "others" and not about those who have been there for a long time and pay their taxes. In many cases, the tourism impact in the high season brings about increased costs of consumer goods (e.g. fresh fish and other foodstuffs) also for the residents; moreover, tourist resorts, such as vacation villages, may tend to be selfreferential, with few job opportunities for the locals. In these cases, the perception of the tourism impact is not positive and there are legitimate doubts about the opportuneness of planning the hospitable city, let alone if we add the Made in Italy tag which the destination reinforces and characterizes.

In parallel, the passage from localism to cosmopolitanism is not something that is realized with communicative rationality and moral suasion by presumed "enlightened" people toward "closed-minded" masses. It activates the context of socially diffuse resistances in which advantages are lost, such as the "positional gains" of those who are not competent in managing the innovations and are content that things remain as they are because they are elderly and not very proactive or because they are convinced that the art of making do will save them no matter what happens. If not adequately guided, the passage activates resistances that limit participation.

In large multifunctional cities and in small rural towns, in northern and southern Italy, the passage to management of spatial mobilities as a focus of urban and territorial planning places in doubt the centrality of the immobile people who wish to remain so because they are mistrustful of outsiders and orientated toward shared mistrust (e.g. they are suspicious of the opportuneness of collaborative partnerships because the players have always operated in an individualistic manner and they think that this is the one best way, the only way to operate, and that the model of working groups and network is only an abstract ideal). From Villa Adriana in the province of Rome to Noto in the province of Syracuse, most residents, even including some public administrators, prefer to live in "modern" houses which they have built illegally, and they still cannot understand why UNESCO (UNESCO, what's that?) has defined those places as "World Heritage Sites". They fail to see them as a personal patrimony: many people think that the "real" problems are different and that those "ruins" and "old buildings" are extraneous to their needs. Tradition as a heritage connecting the local to the global is seen only as an "idea" imposed from above; often the behaviours of the locals demonstrate that they do not feel tied to tourist mobilities as a vehicle of a trend toward cosmopolitanism, which also involves them in modifying attitudes and endogenous relationships within the local community and thus finally the urban policies, shifting the attention to flows and mobilities.

\section{Neo-Community and Relational Diagnosis}

The preliminary diagnosis or self-assessment is neo-communitarian and relational (Murphy, 1985; Guidicini \& Savelli, 1999; Savelli, 2008; Pearce, Moscardo, \& Ross, 1996; Moscardo, 2008; Nunkoo \& Ramkissoon, 2010) because it involves various segments of the local population to re-invent the local community toward hospitality (a neo-community composed of locals and visitors) and because it develops specialized exchanges and professional competencies in managing the net- 
work model of the destination as a collective company that puts to work sectors which up to then had been weakly connected or separated (system). The diagnosis is useful because it reduces the risks of having to turn back in the planning of an experiential tourism product to rediscover, but too late, the good reasons of a "true" collaboration between public and private, a collaboration that was not undertaken because it had been decided to proceed by a shortcut or to ignore some strategic problems, pretending that nothing untoward would have happened.

In reality, we know how things will end already in the initial phase. The pre-conditions and motivations of the local population and stakeholders of "expanded tourism" are, as mentioned above, the genetic material, the DNA, that gives rise to the innovative creative group; this group will become united and international if this evolution is inscribed in the socio-political and cultural heritage of the proponents from the start. Either it exists (and it needs to be enhanced for the growth of the hospitable community) or it does not (and it needs to be grafted on via the hybridization of knowledge). Otherwise, as often happens, if the knowledge and skills at the beginning are mediocre -for instance, the localists predominate over the cosmopolitans - the project to enhance the experiential tourism products will also be mediocre and the groups will be constituted without drawing along the associated players, connected in an intermittent but constant and fluid manner to the network being constituted from "the bottom up".

\section{Self-Assessment Phases}

\section{A Sociological Approach to the Destination Marketing}

Unfortunately, only some English language manuals specify that the governance of the district/system/network and the Development Plan should involve an approach in which participation is an integral part and considered a necessary activity that encourages the talents of the civil society. The liberal approach is more complex in Italy than in countries with an Anglo-Saxon juridical (and also general) culture because the civil society is very weak and politicians must also play the proactive role, currently little practised, of meta-manager of local tourism development, developing specific competencies. Nevertheless, I have had the manual by Godfrey and Clarke (2002) translated, while Steven Pike wrote an excellent manual, still in English, on how to practise destination marketing (2008). Instead, the manual by Ejarque (2009), an introductory tool to territorial marketing, like so many other texts (Pechlaner \& Weiermar, 2000) completely lacks national and international bibliographical references on the essential problems of how to make things happen and how the marketing plan of the destination is effectively applied and not consigned to a drawer, wasting time and money.

To avoid this and to overcome the limits of marketing formulas which seem practical but then nothing happens, the (apparently more theoretical) phases of the self-assessment leave more lasting traces. In fact, they put the people to work without the pretension of explaining with the manual the one best way, the (apparently) definitive solution for all the problems. The llan compiled by an expert is not the solution to the local problems; instead, the one written by locals with expert guidance is a good start to resolve such problems according to freely chosen and interpreted methods because they are based on rules and commitments undertaken during the self-assessment process.

How can the first phase be managed to begin a network system for the enhancement of the immaterial and material patrimony, defined in brief as community self-assessment? It consists of the following steps, which must follow a chronological order and must not become entangled.

\section{First Step: Self-Assessment of the Positive and Negative Impacts of the Tourism Flows on the Environment, the Economy and the Local Culture}

In the forum, the sociologist-facilitator links the assessments to the governance of the variables via a structured organizational system such as a network territorial organization. The solution to the problems and the maximization of the advantages depend on the regulatory-systemic approach, which seems to be the optimal solution to resolve collective problems and to sell a destination as a unitary product recognizable by the targets to be knowingly and selectively attracted and welcomed. It serves to make people think in a general, not particularistic, manner about the destination area as a potential collective player, encouraging the formation of creative groups. From this point of view, a conference on "sustainable development" is more than sufficient to define a debate which, initiated in the early 1980s, is now present in the general economic (and not only tourism) policies of the UNO, European Union and many inter-governmental accords, also on a regional scale. The guiding idea is that rules can avoid the negative impacts of mass tourism and that there are macro- and micro-techniques which can successfully manage the tourism flows, with long-term benefits for the local populations, for the incoming enterprises and for the wellbeing of the hospitality workers.

The sociologist-facilitator uses Table 1 to demonstrate that "anti-tourism apocalypticists" are exaggerating and that laxity destroys destinations. It is all a question of rules that operate between public interest and bottom-up development centred on the enterprises (Costa \& Martinotti, 2003). We begin from below left, when there is low regulation at the destination because the flows are also low. Occasional alternative tourism (OAT) is the virgin destination where few tourists arrive. But it is no longer true that we pass obligatorily to unsustainable mass tourism (UMT), typical of high-season destinations dominated by demand, which are crowded, unliveable and unbearable. The rules of sustainability have also given rise to planned alternative tourism (PAT), disciplining the flows with macro- and microtechniques of territorial management, making them compatible with the environment: the establishment of national and regional natural oases and parks belongs to PAT. Yet, even mass destinations have introduced rules of eco-management with the mark of ecological quality to limit the negative effects of the masses, with the consequent realization of sustainable mass tourism (SMT). SMT is also governed by the de-seasonalization of flows. This model rejects the pessimistic view of the necessary decline of resorts because the sustainable tourism industry can reconcile protection of resources and their enhancement for aware and responsible tourists, post-mass. The dependent variable is given by the rules the local players are able to produce and enforce in order to conserve the natural and cultural resources for future generations.

Therefore, sustainable tourism does not represent the usual frontier of environmentalism but an opportunity to enhance and exploit the local resources of Italy, the functional integration 
Table 1.

Local community and regulation.

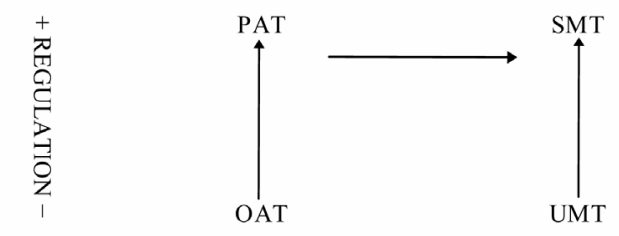

FLOW

Note: Source: Costa (2005) and Weaver (2000).

between Italy's historical and cultural heritage, its natural parks, agricultural sites, excellent industrial and handicraft activities. Increasingly, sustainable tourism constitutes a new code of ethics of travel know-how, a lifestyle that permeates the evolution of the entire sector, which characterizes the methods of use of the tourism product, connecting the typicality of the products to the development of the local offer systems. In parallel, it directs public and private investments toward the environmental quality of the territory and toward the eco-management of the tourism structures, which is obtained via the diffusion of information and the training of tourism workers. In particular, giving a central place to the network organization of the offer, it requires that the stakeholders, beginning with the entrepreneurs and the workers, know how to "harmonize" the solutions accompanying the innovation driven by ideas and by reflection induced by sustainable tourism as a thoughtful conscience of globalization.

The acceptance of this perspective, via the transfer of "formal" knowledge to the "informal" knowledge of the public and private local tourism players, is the condition able to reconcile the territorial marketing with the guiding ideas of sustainable tourism. In fact, Ritchie and Crouch (2005) wrote a manual on how to manage the competitive destination according to the sustainable tourism perspective. More in general, the theory of regulation of tourism flows should be applied to the tourism districts or systems of Made in Italy hospitality. Accordingly, the territorial marketing plan is aimed at modelling the destinations from UMT toward SMT exactly because the environmental and socio-cultural context constitutes the receptacle of the new contents or the new tourist products, realized "among" and "by means of" the sectors of excellence: gastronomy, art and archaeology, fashion, etc.

\section{Second Step: Self-Assessment of the Preconditions and Motivations That Induce the Local Players to Make Pacts or Alliances, to Create Collaborative Partnerships}

The community self-assessment is conducted via the socioterritorial diagnosis of the behaviours assumed by the local players in response to the strategy of operating in a systemic manner to generate the products of the hospitable city with the residents and visitors. It serves to induce the emergence of the interests in play and to enhance leadership and coordination.

During a public forum, the expert-facilitator seeks to make the local stakeholders reflect on the difference between the top-down model and bottom-up model, orienting the debate so as to prevent abrupt and useless contrasts between the two. For this purpose, he can make use of Table 2.

The second model is more suitable for the network business model, but this is not an act of faith: the learning community (the sociological framework of the knowledge management) discusses the topics proposed by the table, trying to adapt the discussions to the local case, to its specificity. In fact, no destination is equal to another nor must it undertake to become so, exactly because the local groups are called on to interpret the orientation schemes and to produce original solutions, specific to the places interconnected by services.

The sociologist-facilitator describes the table, clarifying the concepts by means of comparison between the top-down model and the bottom-up model, item by item. Indeed, the advantage consists in the fact that the table constitutes an orientation compass to decide, in general, what can be the advantages of a bottom-up self-organization which is also institutionally covered and legitimized from the top, such as national and regional laws aimed at encouraging and regulating tourism development with network models. Within the self-assessment of the preconditions, a question is raised that is less institutional and more related to the forms of participation in collaborative marketing that innovates already consolidated business practices.

The improvement process that the self-assessment triggers can be described with Table 3, modified from Watkins and Bell (2003). Naturally, the objective of the network model is tourism development, measurable in the course of the years, and not that of collusive collaboration aimed at access to regional public resources, which are thought of as the greasy pole, in which what counts is to do a lot of elbowing and gain access to public monies so as then to distribute them to clients. In the latter case,

Table 2.

From Governance model to Participation-consensus model.
- From: Large project, with predefined funding

- From: Institutional leadership

- From: Top-down planning

- From: Proactive public authority

- From: LTS sufficient to initiate the process

- From: Top-down decision-making process

- From: High organizational and institutional costs, financed

- From: Sectorial hypotheses and competent public authorities
- To: Smaller project, open to progressive bottom-up development

- To: Local operational leadership by entrepreneurs

- $\quad$ To: Shared vision, but locally defined plans

- To: Proactive public authority, but at the service of the local community

- To: LTS requiring professional operational competencies

- To: Local operational decision-making process, in small irreversible steps

- To: Only operational costs, with local participation

- To: Sectorial hypotheses and non-competent public authorities
Note: Source: autonomous elaboration. 
Table 3.

From competitive fragmentation to collusive (and then innovative) collaboration.

\begin{tabular}{|c|c|c|c|}
\hline \multicolumn{4}{|c|}{ Types of experiences } \\
\hline Dimensions & Fragmented competition & Cooperation & Collusive collaboration \\
\hline Time & $\begin{array}{l}\text { Immediate, often in response to actions } \\
\text { of competitors }\end{array}$ & $\begin{array}{l}\text { Short- to medium-term, often in response } \\
\text { to projects initiated by the hospitality } \\
\text { industry }\end{array}$ & $\begin{array}{l}\text { Long-term, often in response to existing } \\
\text { agreements }\end{array}$ \\
\hline Trust & $\begin{array}{l}\text { Minimal, there is no trust in other } \\
\text { businessmen of the sector }\end{array}$ & $\begin{array}{l}\text { Low to medium, toward the main } \\
\text { organizer and collaborative players }\end{array}$ & $\begin{array}{l}\text { High among the closest members, the } \\
\text { others develop it in relation to the results } \\
\text { and if they adapt themselves }\end{array}$ \\
\hline Involvement & Mainly self-oriented & Generally low, relatively easy to obtain & $\begin{array}{l}\text { Medium to high, obtained with "useful” } \\
\text { but not necessarily "true" results }\end{array}$ \\
\hline Goals & $\begin{array}{l}\text { Short-term, directly linked to the } \\
\text { financial performances and easily } \\
\text { measured }\end{array}$ & $\begin{array}{l}\text { Medium-term, linked to the stimulus for } \\
\text { the business but not readily measured }\end{array}$ & $\begin{array}{l}\text { Long-term, linked to the opportunity to } \\
\text { consolidate the business and not easily } \\
\text { measured }\end{array}$ \\
\hline Beneficiaries & $\begin{array}{l}\text { Gains mainly limited to the } \\
\text { organization }\end{array}$ & $\begin{array}{l}\text { Gains for the members of the } \\
\text { organization and often for the region }\end{array}$ & $\begin{array}{l}\text { Gains for the members of the } \\
\text { organization and for the region }\end{array}$ \\
\hline $\begin{array}{l}\text { Decision-making } \\
\text { process }\end{array}$ & Individual, limited to the results & $\begin{array}{l}\text { The decisions are made by "strong" } \\
\text { individuals or by small groups which } \\
\text { convince the others to follow them }\end{array}$ & $\begin{array}{l}\text { The market shares are orientated by } \\
\text { consensus }\end{array}$ \\
\hline
\end{tabular}

Note: Source: Watkins and Bell, 2003 (modified by the author).

the present study is perfectly useless and the reader is invited to look elsewhere, since the strategic objective is to favour collaborative partnerships for the competitive innovation of network products which produce a "leap forward" of the destination as a collective company based on loose, specialized, creative exchanges and concretely measurable productive actions. Nevertheless, the presentation of Table 3 allows us to reflect on the fact that innovation through collaboration must still be written; it is the vertical column that does not yet exist. And to construct a new modus operandi we have the network institutional organism to be planned as a tool of governance of change.

The facilitator of the aggregative processes, on behalf of the Promotion and Management Committee of the network organization, describes the contents and variables that accompany the process of change from head-to-head competitive fragmentation to collusive collaboration guided by leaderships oriented toward the control of resources, and then on to the invention of good practices in which are dictated the rules, rather loose but generated in an aware and responsible manner, concerning the strategic and operational guidelines of innovation born from many-to-many collaborative marketing.

\section{Fourth Step: Self-Assessment of Whom We Want to Invite. The International Middle Class?}

It has already been mentioned that not all types of tourists are suitable to the destination and it is necessary to proceed in a selective manner to avoid territorial incompatibility with various users. In general, those to be selected as targets are those in a growth phase. If the objective is cultural tourism, the sociologist-facilitator will demonstrate that the resources of the material and immaterial heritage are highly appreciated by the new international middle class, self-confident consumers accustomed to purchasing services on-line, to dealing with the risks of trips, to carrying out sporting and cultural activities at the destination (Costa, 2008; Gretzel \& Jamal, 2009; Valencia \& Crouch, 2008). If this is the choice, the arrivals and presences at the destination do not count, the tourist expenses count. In this case, we want well-off professionals. We do not want the masses, we want cultured, sophisticated, elegant people able to assess and appreciate re-invented tradition, the tradition that comes after the tradition, which the stakeholders have begun to purposely build in the preceding phases of bottom-up planning legitimized from the top by regional directives.

Reducing mass tourists and inviting tourists of the high-value tertiary sector is a strategic choice in tune with the general changes of contemporary capitalism. We are dealing with increasing the flows already present at the destination: advertising agents, information technologists, designers, international lawyers, entertainment people, biotechnologists, doctors, etc., coming from all over the world. Indeed, the immaterial heritage events are co-produced by professionals who want to re-invent a tradition they feel is their own, their chosen one, because they have bought or rented a house. They are the medium of re-invented authenticity. They should be welcomed inside a creative, innovative neo-community, which considers worth and talent a source of pride and a lifestyle, realigning the quality of the offer with the expectations of the professionals placed at the centre of the process of improving the offer.

How do the players of the post-industrial society, of the highvalue tertiary sector dominated by workers who make scientific/cultural knowledge a distinctive resource, spend their free time and tourism? The new middle class has been defined as "city users" (Martinotti, 1993) to underline the distinctive characteristic of mobility "among” cities, expressed mainly by mobile people who mostly live in a post-industrial city, carrying out creative activities (Florida, 2002). The middle class tourist types are nothing but a part of consumers who use the city to exploit its recreational and cultural aspects, incorporated in a unique lifestyle (this is the case of metropolitan businessmen who travel for business, frantically taking part in work meetings or specialized fairs). Who are we talking about? In the early 1990s, a new international middle class was identified, different from mass tourism on the organizational, motivational, vo- 
cational, behavioural levels and with a capacity for mediumhigh expenditure, especially for the acquisition of cultural goods. It is characterized by:

1) "professionalism" in travel know-how (congress and business tourism, frequent flyers, low-cost consumers, short breaks, etc.): the players travel in a desynchronized manner because they are self-employed or because, if employees, their collective contracts have favoured very short weeks and they opt for long "weekends" and reduce the period of the "main vacation". They do not like the "single mouthful" trip but that of "many morsels". They do not have to adjust to the tourism services, the services must be flexible enough to be chosen separately and recombined to adapt to the subjectivity of the tourists/travel know-how professionals. They are characterized by intermittent connections;

2) "intellectualization" (search for active roles in order to learn with the five senses, polysensoriality): learning is connected to "play" for which the tourist trip continues the polysensorial "pleasure" of expanding the exploratory instinct, alternating many activities, from sport to spiritual experiences (supermarket of the "sacred", gleaning a bit of Buddhism, which is particularly liked, and yoga practices, intermixed with diets promising to "put you in good shape") or experimentation with local foods with solitary walks or bicycle trips. The travellers become interpreters of the local cultures which they love to re-invent and relive;

3) "cosmopolitanism" (mental opening to all types of social and cultural differences and appreciation of biodiversity, following the influence of the values of sustainable tourism). In particular, themes of sustainability have influenced the urban and territorial policies of tourism; thus, the introduced rules are part of the new lifestyle of the international middle class, which appreciates the local players if they regulate environmental impacts because it seeks to respect them (code of ethics of aware or responsible travel know-how, with respect to the plurality of cultures to be preserved for future generations of tourists).

The collective subject of the middle class is recognizable on the basis of tourist consumption. It is not a pressure or interest group. It does not act, like unionized workers, with a collective logic to exert organized pressure, such as the acquisition of paid vacations or reduction of the hours worked. It is misleading to label it politically. The international middle class of city users is the consequence of complex economic and socio-cultural dynamics which delineate the trend toward a tourist lifestyle, defined by many as post-mass tourism analogous to post-industrial or post-modern. It is the tip of a "long-term" socio-cultural iceberg.

Stebbins (2007) defined this segment as serious leisure, which is the systematic pursuit of an amateur, hobbyist or volunteer core activity. The travellers find this activity so substantial, interesting and fulfilling that, in the typical case, they launch themselves into a (tourism) career centred on acquiring and expressing special skills, knowledge and experience. Serious leisure has been typically contrasted with "casual" or "unserious" leisure, which is considerably less substantial and does not offer the kind of career just described. A quality distinguishing serious tourists is the opportunity to follow a (tourism) career in the endeavour, a career shaped by its own special contingencies, turning points and stages of achievement and involvement. The participants in serious leisure make a significant effort and play an active role using their specially acquired knowledge, training or skill in sport, culture, gastronomy, etc.
(Stebbins, 2007, 2012).

In our society, the clear opposition between "strain" of work (full of content but disliked on account of the assembly line rhythms and hierarchical organization) and "escape" ("vacation" of content, characterized by liberated fun, by "doing sweet nothing" or by a lethargic lifestyle during the main vacations spent at the sea) is being eroded. The lifestyles of the "new" social groups highlight clusters different from those of mass tourism. There is no longer the trip as "doing sweet nothing”, centred on escape and recreational components, for which the "vacation" is empty of values because it must compensate a repetitive job via the dream of fantastic experiences centred on the "good life", imitating the high consumption of aristocrats. Instead, we are dealing with "minds full of ideas" that wish to remain so throughout the year. These are people who are seeking relationships between work and tourism. The trip of any type is considered a contribution to the enrichment of one's personality and job; it is no longer "something other" than work, but is done with pleasure because it is related to innovation, creativeness and self-realization.

The tourist demand expressed by the new middle class is increasingly multi-motivated, and flexible, desynchronized, personalized, interactive/relational, friendly. It has formed during the last 20 - 25 years and is growing to the point that it is a true "creative class" which uses its free time in an active way to reconcile play and work, aesthetics and productivity. And the "mobility" among cities is typical of creative people: they do not aspire to work in the same city for their whole life but "take flight" to various cities interested in becoming hospitable in order to welcome them as best possible because their presence enriches the economy and the culture of the cities in which they operate for a certain period of years. The use of their "knowledge" is the most important productive factor to achieve success, just as once the raw materials and the "material" energy sources were essential for the industrial society to make products of mass consumption. In Italy, the new international middle class is present in the Cinque Terre area, in the Monferrato area, in Chiantishire, at Ravello, in the Trastevere district in Rome, in some areas of Sicily, and in few other areas because it increasingly prefers countries other than Italy.

To host this class, purposely selecting it with collaborative marketing, the facilitator of the collaborative processes seeks to make the players think about where to position the innovative project in relation to endogenous social cohesion and internationalization by means of awareness and subsequent sale of tourism goods and services for the new international middle class. It is not the visitors who must adapt to the destination but the destination operators who must adapt to the visitors in order to satisfy them by improving the offer. Table 4, based on the geographical approach of Dematteis and Governa (2005) with modifications, can be used for this purpose.

The players invited to the introductory forum reflect on "where" they think the TD should be positioned in the realization phase. Most of them will probably place it in the lower quadrants, between "fragmented self-centred" and "fragmented open". The model has the advantage of stimulating dynamism and inducing the participants to think about what to do to enhance endogenous cohesion and improve the cosmopolitan skills to attract the professional middle class. In substance, it visualizes the course to take to reach the "ideal" destination of the open and integrated TD, the above right quadrant. The table invites the local communities and the inter-communities to 
Table 4.

The TD according to the intensity of collaboration and internationalization.

\begin{tabular}{ccc}
$\begin{array}{c}\text { High intensity } \\
\text { Endogenous } \\
\text { relations }\end{array}$ & United self-centred TD & Integrated open TD \\
Low intensity & $\begin{array}{c}\text { Fragmented } \\
\text { self-centred TD }\end{array}$ & Fragmented open TD \\
& Low intensity & High intensity \\
& \multicolumn{2}{c}{ Supramunicipal relations } \\
\hline
\end{tabular}

Note: Source: Autonomous elaboration based on De Matteis and Governa (2005).

operate with loose and fiduciary, specialized and creative exchanges, as if they were a Made in Italy hospitality district combining civic pride and ambitions of well-being because they want to be protagonists in the new economy of networks and experiential capitalism.

The reflection on expansive glocalism, with the corollary that cultural goods are not sufficient but that services modelled on the expectations of the international middle class are needed, will reduce the risks of creating the usual dichotomy between promotion of the image and marketing of the goods and services. We know that the promotional mix is aimed at the sale of products designed to satisfy a precise target, whose presence excludes targets with different lifestyles.

\section{Consequences: TPD (Tourism Policy Document)}

After this work of bottom-up planning, the level of agreement among the various players, small and large, public and private entities, is formalized in a Tourism Policy Document (TPD). The TPD is written in a loose manner, along general lines, because it delineates a policy of marketing management of the destination area based on the material and immaterial heritage of the resources (Godfrey \& Clarke, 2002, for how the Document is written; Granovetter, 1998, for the concept of strength of weak ties, which correspond to the loose ones, to mark the specialized and non-oppressive aspects such as those of closed communities).

The TPD serves exclusively to reach the objectives of inclusivity of the players with distinct skills and goods/services which can effectively exchange within the territorial and communicative network being constructed. In other words, it is written in such a way that the greatest possible number of local players can be recognized. It serves as a basis because the public institutions and companies, single or in partnership, can decide on their participation in the network inter-organizational model or in the strategic plan of tourist utilization of the network experiential products which the same players, with precise timing, undertake to realize. These are final products due to the innovative collaboration (endogenous cohesion) to directly or indirectly connect the destination, alternating the short networks with the long ones, to the clusters of demand to be determined in detail in a subsequent development plan. However, the TPD is binding on some points (for instance, it is also shared by private players and only those who give something can receive something in exchange) to ensure that the operational meetings not become mere rituals to attract financial resources.
Therefore, unlike Trigilia (2005), Piselli and Ramella (2008) and Ciapetti (2010), I believe that it is not the "decisionist illusion" to underestimate the need of greater collaboration in the different phases of the decision-making process among the various public and private players in initiating innovation, but rather the underestimation of ungoverned fragmentation, as underlined by the cited model of Watkins and Bell. The decisionist illusion is overestimated by various theorists of local development because the true problem is that each person thinks for himself and the spreaders of doubts, including the non-existent fear of the decisionist illusion, indirectly contribute to feeding this fragmentation. The anti-decisionism theorists do not elaborate procedures in which the pacts are maintained and there is not formed an élite which justly applies sanctions, via incremental solutions, to whomever is not changing and is wasting time. The TPD serves to cement a local élite that wishes to govern the processes with strategic choices or incremental decisions requiring selectivity and priority in the choice of the clusters of demand (not all types of tourists are suitable to the destination) and that is aware that "not all the locals can exchange with all” (some locals are excluded because they have nothing to exchange or are incompetent). In fact, the TPD does not reproduce the model of laws aimed at "helping" enterprises but a new model, that of the creative group and of working together.

As underlined by the failure of assistance to enterprises (De Blasio \& Lotti, 2008), the inter-organizational model supports those who would undertake innovation or would start a new network enterprise, apart from the presence of such an organism, because they believe in the new business models and are convinced of being able to do so with their own abilities but know that with the network organization they can overcome many company limits and operational marketing limits. Therefore, the TPD is loose in the opportunities offered but not generic because it is held back by the fear of decisionism. It is open to the methods of socio-economic exchange and, contemporaneously, it delineates executive projects (to be tested during subsequent focus groups) on which to have the players converge, it sets precise limits within which the collaborative partnerships are asked to move.

The TPD activates mechanisms of internal competition. It places at the centre the entrepreneurial activities of the players of tourism, hospitality, transport, culture, agriculture, environment, gastronomy, fashion, sport and other sectors connected to the ever more numerous international mobilities.

\section{Conclusion: The Sociologist as Facilitator for the Initiation of Collaborative Marketing of "Made in Italy” Hospitality Networks}

This article has highlighted the up skills of the sociologist/ facilitator of tourism development. The sociologist/facilitator knows "how to" ensure that the players of the economy, tourism, art, fashion and gastronomy meet, dialogue and begin to work on a "strategic project" to be assessed through focus groups and to be realized through policy documents created in a bottom up manner. As applied sociologist, he/she is a "craftsman” (Hartmann \& Sonnad, 2007) of the local development.

How can the results of his action be assessed with respect to the expectations concerning these results? One positive result is the very fact that people belonging to different sectors and unknown to each other prior to his facilitation discover that they 
have common interests and that they can benefit from "giving in order to be able to receive something in exchange". The success is total if the TPD is included in the destination manager's agenda-setting and it helps to realize a broader policy aimed at improving the quality of life of the residents and the visitors, the "hospitable city" (Costa, 2005, 2008).

The analysis of Italian hospitality, in which the stakeholders try to integrate tourism resources and other resources connected to hospitality (e.g. fashion, food and wine, arts and archaeological areas), demonstrates that the sociologist/facilitator knows how to contemporaneously use qualitative and quantitative studies. The two types of studies are complementary in the practical activity of bottom up planning inspired by sustainable tourism (for confirmation, Davies, 2003; Riley \& Love, 2000). What counts is including the knowledge in participatory and shared bottom up planning with precise and clear objectives. Applied sociology does not seek truth but helps the players to decide in an aware manner by facilitating communicative rationality among the stakeholders.

What inter-organizational model is suitable to plan and promote hospitality? The present study has provided an answer: the mobile network model for the new mobilities of contemporary society (Urry, 2007; Larsen, Urry, \& Axhausen, 2007; also Adey, 2010). Following the results and advice of the international literature, it is necessary to begin a program of bottom-up sensitization to provide public administrators and entrepreneurs with higher-level skills so that they are able to understand and satisfy the needs of the new international middle class of city users (Martinotti, 1993) or leisure tourists (Stebbins, 2007, 2012) or new creative middle class (Florida, 2002). The destination's tourism operators are also required to be creative and professionalized like the customers they wish to host. They must contribute to the enhancement of the material and immaterial culture, they must have the lifestyle of the visitors. They must become professionalized, intellectualized and cosmopolitan. This path of change can be accelerated by relying especially on young graduates in tourism disciplines who have also studied abroad and by favouring the most competent among them. To this purpose, the marketing of cultural tourism products is devised by the economic players under the direction of an external facilitator who helps them move, during the seminars and focus groups, from passive acceptance of mass tourism to regulation of community-oriented tourist flows, from the model of top-down governance to the model of bottom-up governance, from individualism to competitive collaboration, from localism to expansive glocalism.

In this context, LTS, TD, CD can be realized and "true" strategic plans can be approved as consequences of a collaborative vision of local development, whose performance is measured on the basis of the economic results achieved through the years. In fact, the products characterized by immaterial culture and material culture become "product clubs" and the governmental organ of the district or system (they are the same thing) tries to combine the promotion and sale of these products. What counts is innovating with proposals modelled on the needs of the international middle class, which must be satisfied in order to spend more, to begin positive word-of-mouth marketing and to accept small price increases year after year (thus reducing the costs of the incoming enterprises in the promotion and management of the flows) because it acquires fidelity to the destination and to the enterprises.

The tourism district must be considered a large supermarket of Made in Italy hospitality defined in terms of quality and local uniqueness. The tourist enters the destination convinced of buying only a few things and leaves with a shopping cart full of goods. He has been seduced by the destination manager, who, supported by the long work of planning initiated with the neocommunity and systemic self-assessment, has accompanied him to see places adapted to his expectations so as to help him happily spend where the locals want him to spend. The metaphor of the shopping cart full of goods describes whether the district or system (and any strategic plan) has been successful.

The difficulties that stakeholders have encountered in realizing territorial networks of Made in Italy hospitality are due to limits in the knowledge management of the local institutions and the incoming tourism entrepreneurs. Recourse to the expertise of the sociologist/facilitator, who accompanies the processes of development with a good theory in mind and pragmatism in knowing how to create the networks and systems (philosophic practitioner), can help the locals overcome the limits of their knowledge, which in turn limit the success of the participatory planning.

\section{REFERENCES}

Aas, C., Ladkin, A., \& Fletcher, J. (2005). Stakeholder collaboration and heritage management. Annals of Tourism Research, 32, 28-48. doi:10.1016/j.annals.2004.04.005

Adey, P. (2010). Mobility. London and New York: Routledge.

Apostolopoulos, Y., Leivadi, S., \& Yiannakis, A. (1996). The sociology of tourism. Theoretical and empirical investigations. New York: Routledge.

Biork, P., \& Virtanen, H. (2005). What tourism project managers need to know about co-operation facilitators. Scandinavian Journal of Hospitality and Tourism, 5, 212-230. doi:10.1080/15022250510014354

Branwell, B., \& Lane, B. (2000). Tourism collaboration and partnerships. Clevedon-Sydney: Channel View Publications.

Ciapetti, L. (2010). Lo sviluppo locale. Bologna: Il Mulino.

Cooper, C. (2006). Knowledge management and tourism. Annals of Tourism Research, 33, 47-64. doi:10.1016/j.annals.2005.04.005

Costa, N. (2005). I professionisti dello sviluppo turistico locale. Milano: Hoepli.

Costa, N. (2008). La città ospitale. Milano: B. Mondadori.

Costa, N. (2009). Urban tourist system as Made in italian districts and the new international middle class of creative city users. In D. Diamantini, \& G. Martinotti (Eds.), Urban civilization, from yesterday to the next day (pp. 371-393). Napoli: Scriptamanent.

Costa, N., \& Martinotti, G. (2003). Sociological theories of tourism and regulation theory. In L. M. Hoffman, S. Fainstein, \& D. R. Judd (Eds.), Cities and visitors. Regulation people, markets and city space (pp. 53-71). Londra: Blackwell.

Costa, N., \& Testa, S. (2012). Web marketing e destinazione ospitale. Milano: McGraw-Hill.

Dall'Ara, G., \& Morandi, F. (2006). I sistemi turistici locali. Normativa, progetti e opportunità. Metelica (MC): Halley.

Dann, G. M. S., \& Liebman, P. G. (2009). The sociology of tourism. European origins and developments. Oxford: Emerald.

Dasgupta, S., \& Driskell, R. (2007). Discourse on applied sociology. London: Anthem Press.

Davies, B. (2003). The role of quantitative and qualitative research in industrial studies of tourism. International Journal of Tourism Research, 5, 97-111. doi:10.1002/jtr.425

De Blasio, G., \& Lotti, F. (2008). La valutazione degli aiuti alle imprese. Bologna: Il Mulino.

Della Corte, V. ( 2009). Imprese e sistemi turistici. Milano: Egea.

Dematteis, G., \& Governa, F. (2005). Territorialità, sviluppo locale, sostenibilità: il modello Slot. Milano: FrancoAngeli.

Dredge, D. (2006a). Networks, conflict and collaborative communities. 
Journal of Sustainable Tourism, 14, 562-581. doi: $10.2167 /$ jost 567.0

Dredge, D. (2006b). Polity networks and local organisation of tourism. Tourism Management, 27, 269-280. doi:10.1016/j.tourman.2004.10.003

Ejarque, J. (2009). Destination marketing. Milan: Hoepli.

Florida, R. (2002). La nuova classe creative. Milan: Mondadori.

Fyall, A., \& Garrod, B. (2005). Tourism marketing. A collaborative approach. Channel View: Clevedon.

Godfrey, K., \& Clarke, J. (2002). Manuale di marketing territoriale per il turismo. Firenze: Le Monnier.

Granovetter, M. (1998). La forza dei legami deboli e altri saggi. Napoli: Liguori.

Gretzel, U., \& Jamal, T. (2009). Conceptualizing the creative tourist class: technology, mobility and tourism experiences. Tourism Analysis, 14, 471-481.

Guidicini, P., \& Savelli, A. (1999). Strategie di comunità nel turismo Mediterraneo. Milano: FrancoAngeli.

Hartmann, D. J., \& Sonnad, S. R. (2007). The applied sociologist as craftsman. In S. Dasgupta, \& R. Driskell (Eds.), Discourse on applied sociology (pp. 165-178). London: Anthem Press.

Holden, A. (2005). Tourism studies and social sciences. London and New York: Routledge.

Jones, D., Jurowski, C., \& Uysal, M. (2000). Host community residents' attitudes: A comparison of environmental viewpoints. International Journal of Hospitality and Tourism Research, 2, 174-189.

Larsen, J., Urry, J., \& Axhausen, K. W. (2007). Networks and tourism. Mobile social life. Annals of Tourism Research, 34, 244-262. doi:10.1016/j.annals.2006.08.002

Lazzaretti, L., \& Petrillo, C. S. (2006). Tourism local systems and networking. Oxford: Elsevier.

Lopez-Cabrales, A., Perez-Luno, A., \& Valle, C. R. (2009). Knowledge as a mediator between HRM practices and innovative activity. $\mathrm{Hu}$ man Resource Management, 48, 485-503. doi:10.1002/hrm.20295

Martinotti, G. (1993). Metropoli. Bologna: Il Mulino.

Mason, R., \& Cheyne, J. (2000). Residents' attitudes to proposed tourism development. Annals of Tourism Research, 27, 391-411. doi:10.1016/S0160-7383(99)00084-5

Moscardo, G. (2008). Building community capacity for tourism development. Wallingford: CABI.

Murphy, P. E. (1985). Tourism. A community approach. New York and London: Methuen.

Naipaul, S., Wang, Y., \& Okumus, F. (2009). Regional destination marketing: A collaborative approach. Journal of Travel \& Tourism Marketing, 26, 462-481. doi:10.1080/10548400903162998

Nash, D. (2007). The study of tourism. Anthropological and sociological beginnings. Oxford: Elsevier.

Nunkoo, R., \& Ramkissoon, H. (2007). Resident's perceptions of the socio-cultural impact of tourism in Mauritius. Anatolia-An International Journal of Tourism and Hospitality Research, 18, 138-145.

Nunkoo, R., \& Ramkissoon, H. (2010). Modelling community support for a proposed integrated resort project. Journal of Sustainable Tourism, 18, 257-277. doi:10.1080/09669580903290991

Pearce, Ph. L., Moscardo, G., \& Ross, G. F. (1996). Tourism сотmu- nity relationships. Pergamon: Pearce, Moscardo and Ross.

Pechlaner, H., \& Weiermar, K. (2000). Fondamenti di marketing e gestione delle destinazioni turistiche. Milan: Touring Club Italiano.

Pike, S. (2008). Destination marketing. An integrated marketing communication approach. Amsterdam-Tokyo: Elsevier/BH.

Piselli, F., \& Ramella, F. (2008). Patti sociali per lo sviluppo. Roma: Donzelli.

Reid, D. G., Mair, H., \& George, W. (2004). Community tourism planning: A self-assessment instrument. Annals of Tourism Research, 31, 623-639. doi:10.1016/j.annals.2004.01.007

Riley, R. W., \& Love, L. L. (2000). The state of qualitative tourism research. Annals of Tourism Research, 27, 164-187. doi:10.1016/S0160-7383(99)00068-7

Ritchie, J. R. B., \& Crouch, G. I. (2005). The competitive destination. A sustainable tourism perspective. Wallingford: CABI.

Sacco, P. L., \& Ferelli, G. (2003). I distretti culturali evoluti. Un nuovo modello di sviluppo locale. Bologna: Il Mulino.

Sacco, P. L., \& Tavani, B. G. (2005). Distretti culturali evoluti e valorizzazione del territorio. Global \& Local Economic Review, 1, 5-17.

Savelli, A. (2008). Spazio turistico e società globale. Milano: FrancoAngeli.

Sciarelli, S. (2007). Il management dei sistemi turistici locali. Strategie e strumenti per la governance. Torino: Giappichelli.

Sheller, M., \& Urry, J. (2004). Tourism mobilities. Places to play, places in play. London and New York: Routledge.

Stebbins, R. A. (2007). Serious leisure. New Brunswick: Transaction Publishers.

Steele, S. F., \& Price, J. (2008). Applied sociology. Terms, topics, tools and tasks. Belmont: Thompson Wadsworth.

Stebbins, R. A. (2012). The idea of leisure. First principles. New Brunswick: Transaction Publishers.

Tosun, C. (2002). Host perceptions of impacts: A comparative tourism study. Annals of Tourism Research, 29, 231-253. doi:10.1016/S0160-7383(01)00039-1

Tovar, C., \& Lockwood, M. (2008). Social impacts of tourism: An Australian regional case study. International Journal of Tourism Research, 10, 365-378. doi:10.1002/jtr.667

Tribe, J. (2002). The philosophic practitioner. Annals of Tourism Research, 29, 338-357. doi:10.1016/S0160-7383(01)00038-X

Tribe, J. (2009). Philosophcal issues in tourism. Bristol-Toronto: Channel View Publications.

Trigilia, C. (2005). Sviluppo locale: Un progetto per l'Italia. Roma-Bari: Laterza.

Urry, J. (1990). The tourist gaze. London: Sage.

Urry, J. (2007). Mobilities. Cambridge: Polity.

Valencia, J., \& Crouch, G. I. (2008). Travel behavior in troubled times: The role of consumer self-confidence. Journal of Travel \& Tourism Marketing, 28, 54-65.

Watkins, M., \& Bell, B. (2003). The experience of forming business relationships in tourism. International Journal of Tourism Research, 4, $15-28$.

Weaver, D. B. (2000). A broad context model of destinations. Development scenarios. Tourism Management, 21, 217-224. 